\title{
Assessment of Yield Limiting Nutrients through Response of Rice (Oryza sativa L.) to Nutrient Omission in Inceptisols of Bastar District of Chhattisgarh State in India
}

\author{
Bhupendra Kumar ${ }^{1}$, G.K. Sharma ${ }^{1 *}$, V.N. Mishra ${ }^{2}$, T. Chandrakar ${ }^{1}$, A. Pradhan ${ }^{1}$, \\ D.P. Singh ${ }^{1}$ and A.K. Thakur ${ }^{1}$ \\ ${ }^{1}$ Shaheed Gundadhur College of Agriculture and Research Station, Jagdalpur- 494005 \\ (Chhattisgarh), India \\ ${ }^{2}$ College of Agriculture, Indira Gandhi Krishi Vishwavidyalaya, Raipur- 492012 \\ (Chhattisgarh), India \\ *Corresponding author
}

\section{A B S T R A C T}

The investigation was under taken during kharif and rabi season 2017-18 at Shaheed Gundadhur College of Agriculture and Research Station, Jagdalpur (Chhattisgarh). The pot experiment, during kharif season with transplanted rice, was laid out under Completely Randomized Design (CRD) with three replications and 11 treatments comprised with

\begin{tabular}{|l|}
\hline Ke y w or d s \\
Site specific nutrient \\
management, Yield \\
limiting nutrients, \\
Nutrient omission pot \\
technique
\end{tabular}
keeping one treatment of application of all nutrients $(\mathrm{N}, \mathrm{P}, \mathrm{K}, \mathrm{S}, \mathrm{Ca}, \mathrm{Mg}, \mathrm{Cu}, \mathrm{Zn}, \mathrm{B}$, and Mo) in optimum level and other treatments were formulated by sequentially omitting each nutrient from all nutrients applied. The result revealed that the omission of nutrients $\mathrm{N}, \mathrm{P}$ and $\mathrm{S}$ significantly reduced the plant height, tillers $\operatorname{pot}^{-1}$, effective tillers pot $^{-1}$, filled grains panicle $^{-1}$, grain and straw yield of rice and uptake of N, P, K, S, Ca, Mg, Cu, Zn, Mn, Fe and $\mathrm{B}$ by rice in comparison to treatment that received all nutrients. The highest grain yield $66.4 \mathrm{~g} \mathrm{pot}^{-1}$ were recorded under the treatment receiving all the nutrients and that of lowest grain yields 34.8 pot $^{-1}$ were recorded under omission of $\mathrm{N}$, followed by omission of $\mathrm{P}$ (42.5 $\left.\operatorname{pot}^{-1}\right)$ and $\mathrm{S}\left(56.3\right.$ pot $\left.^{-1}\right)$ nutrients. Based on these results of kharif season, the limiting nutrients were identified as $\mathrm{N}, \mathrm{P}$, and $\mathrm{S}$. These nutrients were applied at the rate of $150 \mathrm{~kg}$ $\mathrm{N}, 100 \mathrm{~kg} \mathrm{P}_{2} \mathrm{O}_{5}, 100 \mathrm{~kg} \mathrm{~K}_{2} \mathrm{O}, 45 \mathrm{~kg} \mathrm{~S} \mathrm{ha}^{-1}$. This dose, known as SSNM dose was tested at farmers field, from where the bulk soils were collected for pot experiments, with wheat crop during rabi season 2017-18. SSNM dose resulted in higher grain yield of wheat in comparison to that of farmer's fertilizer doses at the rate of $80 \mathrm{~kg} \mathrm{~N}: 50 \mathrm{~kg} \mathrm{P}_{2} \mathrm{O}_{5}: 0 \mathrm{~kg} \mathrm{~K}_{2} \mathrm{O}$ $\mathrm{ha}^{-1}$. About $13.3 \%$ increase in the wheat grain yield were recorded due to SSNM dose based on identified yield limiting nutrients over farmer's practice dose.

\section{Introduction}

Soil fertility evaluation is the key factor for adequate and balanced fertilization of crops in high crop production systems. Soil and plant analyses are commonly performed to assess the fertility status of a soil with other diagnostic techniques including identification of deficiency symptoms and biological tests which are helpful in determining specific 
nutrient stresses and quantity of nutrients needed to optimize the yield (Havlin et al., 2007). However, the analytical results do not indicate the most limiting nutrient according to Liebig's law of the minimum "the minimum nutrient is the factor that governs and controls growth and potential yield of crop". The nutrient omission pot trial provides a visible order of crop response to nutrient application. It aims to find out the most limiting nutrients to the growth of a crop plant. If any element is omitted while other elements are applied at suitable rates and plants grow weakly, then the tested element is a limiting factor for crop growth. Conversely, if any element is omitted but plants are healthy, then that element is not a limiting factor for crop production.

The site-specific nutrient management (SSNM) strives to enable farmers to dynamically adjust fertilizer use to optimally fill the deficit between the nutrient needs of a high-yielding crop and the nutrient supply from naturally occurring indigenous sources such as soil, organic amendments, crop residues, manures, and irrigation water. The SSNM approach does not specifically aim to either reduce or increase fertilizer use. Instead, it aims to apply nutrients at optimal rates and times to achieve high yield and high efficiency of nutrient use by the rice crop, leading to high cash value of the harvest per unit of fertilizer invested.

Among the various cropping systems, rice based cropping systems are the predominant systems in India. Managing the variability in soil nutrient supply that has resulted from intensive rice cropping is one of the challenges for sustaining and increasing rice yield in India. The use of plant nutrients in a balanced manner is the prime factor for efficient fertilizer program. Balanced nutrient use ensures high production level and helps to maintain the soil health and ensures sustainable agriculture (Sahu et al., 2017).
Rice is the most important and extensively cultivated food crop, which provides half of the daily food for one of every three persons on the earth. In our country, more than 40 million hectares area are covered under rice cultivation and total production has crossed 100 million tonnes. Rice production in India is an important factor for food security. However, little is known about the sustainability of the current production systems, particularly systems with triple cropping under minimum practice. Among the various cropping systems, rice based cropping systems are the predominant systems in India. Managing the variability in soil nutrient supply that has resulted from intensive rice cropping is one of the challenges for sustaining and increasing rice yield in India.Looking to very limited information on the proper and site specific nutrient doses to maximize yield of rice, present investigation was undertaken with the objective to assess the yield limiting nutrients based on rice response using nutrient omission technique and to demonstrate the optimum use of identified limiting nutrients and its comparison with farmer's fertilizer practice.

\section{Materials and Methods}

Apot culture investigation for assessment of yield limiting nutrients in soil was undertaken during the year of kharif season 2017at the green house of Section of Soil Science and Agricultural Chemistry, Shaheed Gundadhoor College of Agriculture and Research Station, Jagdalpur, Bastar (Chhattisgarh) and subsequently at farmers field of village Dharmaur, block - Tokapal, District -Bastar for verification of the results of pot experiment. The study site lies at $19^{0} 10^{\prime} \mathrm{N}$ latitude and $81^{\circ} 95 \mathrm{E}$ longitude with an altitude of 550-760 meter above the mean sea level. The pot experiment, during kharif season with transplanted rice, was laid out under Completely Randomized Design (CRD) with 
three replications and 11 treatments comprised by keeping one treatment $\left(\mathrm{T}_{1}\right)$ with application of all nutrients (N, P, K, S, Ca, Mg, Cu, Zn, B, and Mo) in optimum level and other treatments were formulated by sequentially omitting each nutrient from $\mathrm{T}_{1}$ where all nutrients were applied (SSNM).

Before conducting the experiment, the bulk soil samples representative of Inceptisol of the district was collected from the farmer's fields for pot culture experiment to identify the yield limiting nutrients. The initial physicochemical characteristics of the experimental soil (Inceptisol) was determined (Table 1) using common field and laboratory procedures. The mechanical analysis showed that the texture of soil under investigation was a sandy clay loam. The initial status of soil $\mathrm{pH}$ was, recorded as slightly acidic (6.3). Electrical Conductivity (EC) were estimated as $(0.13$ $\mathrm{dsm}^{-1}$ ) and rated as normal. The organic $\mathrm{C}$ was estimated as medium in the soils where it was rated as low. Available $\mathrm{N}, \mathrm{P}$ and $\mathrm{S}$ was estimated as low. Status in available $\mathrm{K}$ was rated as medium and that of available $\mathrm{Ca}$ and $\mathrm{Mg}$ was high. The available $\mathrm{Zn}$ was rated as marginal and the available boron status of the soils was rated aslow, however, the availability of $\mathrm{Fe}, \mathrm{Mn}$ and $\mathrm{Cu}$ was rated as high.

The processed and uniformed soil samples were filled in plastic pots @ $20 \mathrm{~kg}$ and nutrients as specified above were applied through different sources taking care to avoid any precipitation during solution mixing and application. The optimum doses of nutrients were fixed in $\mathrm{kgha}^{-1}$ as $\mathrm{N}-150, \mathrm{P}_{2} \mathrm{O}_{5^{-}} 100$, $\mathrm{K}_{2} \mathrm{O}-100, \mathrm{~S}-45, \mathrm{Ca}-110, \mathrm{Mg}-50, \mathrm{Fe}-20$, $\mathrm{Mn}-7.5, \mathrm{Cu}-7.5, \mathrm{Zn}-7.5, \mathrm{~B}-3$ and $\mathrm{Mo}-$ 0.75 for SSNM dose. Rice (MTU-1001) was taken as test crop. The pots were maintained saturation with standing water and twenty five days old seedlings of rice (MTU-1001) were transplanted on $22^{\text {th }}$ July 2017. Three seedlings of MTU-1001 variety of rice were planted in three hills in each pot and water level was maintained at $3 \mathrm{~cm}$ throughout the crop season. Thereafter, full dose of all the nutrients except nitrogen was added to the soil in solution form. Nitrogen as urea was applied in three splits at transplanting, tillering and panicle initiation stage. The effects of treatments were recorded in terms of yield, different yield attributing parameters and nutrient uptake by rice crop. Based on these results, $\mathrm{N}, \mathrm{P}$ and $\mathrm{S}$ were identified as yield limiting nutrients. The optimum use of identified limiting nutrients was verified at farmer's field, from where the bulk soil was collected, with wheat variety $\mathrm{GW}-273$ as a test crop during rabi season 2017-18 and the effects of optimum/SSNM dose was compared with farmer's fertilizer practice.

\section{Results and Discussion}

\section{Yield and yield attributing parameters}

\section{Plant height}

Omission of different nutrients had a significant effect on plant height of rice crop in Inceptisol at Bastar district (Table 2). Plant height is one of the most important characteristics which indicate nutrients absorption capacity as well as health of the soil and plant.The highest plant height of rice was recorded under treatment $T_{1}$ where all the nutrients were supplied, whereas, significantly lower plant height were recorded under the treatments missing $\mathrm{N}, \mathrm{P}$ and $\mathrm{S}$ nutrients, as compared to $\mathrm{T}_{1}$ indicating the need of application of these nutrients in Inceptisols of the region. Since $\mathrm{N}$ is an important constituent of amino acids, proteins and protoplast, its application had a more pronounced effect on plant growth and development through better utilization of photo-synthates and more vegetative growth. These results are in conformity of the findings of Sharma et al., 
(2000). P omission had also exhibited a significant effect on plant height. Optimum $\mathrm{P}$ availability is essential for normal growth and development and the utilization of other nutrients, particularly N. The significant crop response to $\mathrm{P}$ application was also reported by many workers (Ahmed et al., 2010 and Mc Beath et al., 2007).

\section{Tillers per pot}

The results presented in the table 2 show the effects of nutrients omission on tillers pot $^{-1}$ of rice recorded at 60 DAT in Inceptisol of Bastar district. Significantly higher number of tillers was observed at treatment $\mathrm{T} 1$ that received all the nutrients. However, N, P and $S$ nutrients omission treatments showed significantly less number of tillers in comparison to treatment $\mathrm{T}_{1}$.

$\mathrm{N}$ plays a key role in tillers bearing of rice followed by P. On an average, 23 tillers were observed at 60 DAT with T1 treatment which received all nutrients and various nutrients omission treatments had reduced number of tillers. Omission of $\mathrm{N}$ and $\mathrm{P}$ reduced the number of tillers as these two nutrients have major role in tillers bearing of the crop.

\section{Effective tillers pot $^{-1}$}

Grain yield of cereals is highly dependent upon the number of effective tillers. The data, pertaining to number of effective tillers per pot, presented in Table 2 was ranged from 12.3 to 19.3 . Omission of different nutrients significantly reduced the number of effective tillers of rice.

The highest numbers of effective tillers were observed in treatment $\mathrm{T}_{1}$ that received all nutrients. Omission of $\mathrm{N}, \mathrm{P}$ and $\mathrm{S}$ nutrients significantly reduced the effective tillers of rice, as compared to $T_{1}$ that received all nutrients.

\section{Filled grains panicle ${ }^{-1}$}

The data presented in Table 2 showed that the number of filled grainpanicle ${ }^{-1}$ as affected by various treatments varied from 113.7 to 137.0. Treatment $\mathrm{T}_{1}$ which received all nutrients recorded significantly highest number of filled grains per panicle. Omission of $\mathrm{N}, \mathrm{P}$ and $\mathrm{S}$ significantly reduced the filled grains per panicle, as compared to $T_{1}$.

\section{Test weight}

Test weight (weight of 1000 rice seed) of rice did not differ significantly with respect to the application of different treatments in this study. However, omission of $\mathrm{N}$ and $\mathrm{P}$ pots had reduced the test weight as compared to those of all other treatments. It is universally truth that $\mathrm{N}$ and $\mathrm{P}$ are the most important major nutrients require for tillering, root growth and general plant vigour that affect ultimately filled grains and test weight. The reduced effective tillers, number of filled grains per panicle and test weight were recorded in present study caused due to omission of $\mathrm{N}$ and $\mathrm{P}$ treatments (Table 2).

\section{Grain yield}

The data pertaining to effect of nutrient omission on grain yields of rice in Inceptisol of Bastar district are illustrated in (Table 1). The rice grain yields were influenced significantly with the imposition of different nutrient omission treatments. The highest grain yield $\left(66.4 \mathrm{~g} \mathrm{pot}^{-1}\right)$ were recorded under the treatment receiving all the nutrients (T1) and that of significantly lower grain yields (34.8 $\mathrm{g} \mathrm{pot}^{-1}$ ) in comparison to $\mathrm{T}_{1}$, were recorded under omission of $\mathrm{N}$ followed by omission of $\mathrm{P}$ (42.5 $\left.\mathrm{g} \mathrm{pot}^{-1}\right)$ and $\mathrm{S}$ (56.3 g pot $\left.^{-1}\right)$ nutrients. In other treatments, grain yields were observed statistically at par in comparison to treatment $\mathrm{T}_{1}$ where all the nutrients were supplied to rice crop. 


\section{Grain yield reduction}

The reduction of rice grain yield because of omission of different plant nutrients, from treatment $\mathrm{T}_{1}$ (where all the nutrients applied), were also worked out (Table 2). The yield limiting nutrients which reduced the yield by about $10 \%$ from the maximum yield obtained by treatment $T_{1}$ are critically observed. It was noticed that omission of $\mathrm{N}$ from SSNM dose reduced the grain yield by $47.6 \%$ and that of $\mathrm{P}$ omission caused a yield reduction of $35.9 \%$. Apart from the omission of $\mathrm{N}$ and $\mathrm{P}$, yield reductions due to $\mathrm{S}$ and $\mathrm{Zn}$ omission were also noticed. It was observed that $\mathrm{S}$ omission reduced rice yield by $15.1 \%$ and $\mathrm{Zn}$ omission $11.7 \%$. Percent reduction in rice grain yields under different nutrient omitted pots as presented in Table 1 may be put in the order of $\mathrm{N}>\mathrm{P}>\mathrm{S}>\mathrm{Zn}$. Large reductions in the grain yield of rice were observed with the omission of $\mathrm{N}$ and $\mathrm{P}$ as compared to the other nutrient omission treatments. The yield reductions were more pronounced with $\mathrm{N}$ omission. Result clearly indicates that $\mathrm{N}$ is the most critical nutrients that affect the grain yield considerably in all the soils followed by $\mathrm{P}$. Omission of all other nutrients did not indicate yield reduction, statistically significantly except, omission of S.

\section{Straw yield}

It is evident from the data in (Table 2) that the mean straw yields of rice were significantly affected with imposition of different nutrient omission treatments. Omission of N, P and S significantly reduced the straw yield as compared to treatment $T_{1}$ where all the nutrients were supplied. The highest straw yield $\left(82.3 \mathrm{~g} \mathrm{pot}^{-1}\right)$ of rice was observed in treatment $\mathrm{T}_{1}$ where all the nutrients were applied and lowest $\left(44.2 \mathrm{~g} \mathrm{pot}^{-1}\right)$ in $\mathrm{T}_{2}$ treatment where $\mathrm{N}$ was omitted.

Table.1 Initial physicochemical characteristic of experimental soil

\begin{tabular}{|l|l|c|c|}
\hline S. No. & Soil Characteristics & Value & Rating \\
\hline 1. & Mechanical composition & 54 & Sandy Clay Loam \\
\hline & Sand $(\%)$ & 20 & \\
\hline & Clay $(\%)$ & 26 & \\
\hline & Silt $(\%)$ & 6.3 & slightly acidic \\
\hline 2. & $\mathrm{pH}(1: 2.5$ soil: water ratio $)$ & 0.13 & normal \\
\hline 3. & EC $\left(\mathrm{dS} \mathrm{m}^{-1}\right)$ & 0.52 & medium \\
\hline 4. & Organic $\mathrm{C}(\%)$ & 242 & low \\
\hline 5. & Available $\mathrm{N}\left(\mathrm{kg} \mathrm{ha}^{-1}\right)$ & 10.84 & low \\
\hline 6. & Available $\mathrm{P}\left(\mathrm{kg} \mathrm{ha}^{-1}\right)$ & 182 & medium \\
\hline 7. & Available $\mathrm{K}\left(\mathrm{kg} \mathrm{ha}^{-1}\right)$ & 1062 & high \\
\hline 8. & Available $\mathrm{Ca}\left(\mathrm{kg} \mathrm{ha}^{-1}\right)$ & 463 & high \\
\hline 9. & Available $\mathrm{Mg}\left(\mathrm{kg} \mathrm{ha}^{-1}\right)$ & 17.7 & low \\
\hline 10. & Available $\mathrm{S}\left(\mathrm{kg} \mathrm{ha}^{-1}\right)$ & 0.74 & marginal \\
\hline 11. & Available $\mathrm{Zn}(\mathrm{ppm})$ & 1.45 & high \\
\hline 12. & Available $\mathrm{Cu}(\mathrm{ppm})$ & 27.30 & high \\
\hline 13. & Available $\mathrm{Mn}(\mathrm{ppm})$ & 38.90 & high \\
\hline 14. & Available $\mathrm{Fe}(\mathrm{ppm})$ & 0.47 & low \\
\hline 15. & Available B $(\mathrm{ppm})$ & & \\
\hline
\end{tabular}


Table.2 Effect of nutrient omission on yield and yield attributes of rice (MTU-1001) in Inceptisol of Bastar Plateau

\begin{tabular}{|c|c|c|c|c|c|c|c|c|c|}
\hline \multicolumn{2}{|c|}{ Treatment } & \multirow{2}{*}{$\begin{array}{c}\text { Plant height } \\
\text { (cm) } \\
22.7\end{array}$} & \multirow{2}{*}{$\begin{array}{l}\text { Tillers (numbers } \\
\text { pot }^{-1} \text { ) } \\
22.7\end{array}$} & \multirow{2}{*}{$\begin{array}{l}\text { Effective tillers } \\
\text { (numbers } \text { pot }^{-1} \text { ) } \\
19.3\end{array}$} & \multirow{2}{*}{$\begin{array}{l}\text { Filled grain } \\
\text { (numbers panicle }{ }^{-1} \text { ) } \\
137.0\end{array}$} & \multirow{2}{*}{$\begin{array}{c}\text { Test weight ( } \mathrm{g} \\
\left.1000 \text { grain }^{-1}\right) \\
25.8\end{array}$} & \multirow{2}{*}{ 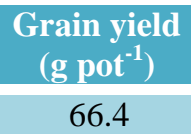 } & \multirow{2}{*}{$\begin{array}{l}\text { Reduction in grain } \\
\text { yield over } \mathrm{T}_{1}(\%) \\
-\end{array}$} & \multirow{2}{*}{$\begin{array}{l}\text { Straw yield } \\
\qquad \begin{array}{c}\left(\mathrm{g} \mathrm{pot}^{-1}\right) \\
82.3\end{array}\end{array}$} \\
\hline $\mathrm{T}_{1}$ & All & & & & & & & & \\
\hline $\mathrm{T}_{2}$ & All - $\mathbf{N}$ & 14.7 & 14.7 & 12.3 & 113.7 & 25.6 & 34.8 & 47.6 & 44.2 \\
\hline $\mathbf{T}_{3}$ & All - P & 16.7 & 16.7 & 14.7 & 117.7 & 25.6 & 42.5 & 35.9 & 52.9 \\
\hline $\mathrm{T}_{4}$ & All - $\mathbf{K}$ & 21.7 & 21.7 & 19.0 & 136.3 & 25.8 & 65.7 & 1.0 & 82.7 \\
\hline $\mathrm{T}_{5}$ & All - S & 19.7 & 19.7 & 16.3 & 130.0 & 25.7 & 56.3 & 15.1 & 71.5 \\
\hline $\mathrm{T}_{6}$ & All - Ca & 21.7 & 21.7 & 18.7 & 135.3 & 25.8 & 64.5 & 2.8 & 80.0 \\
\hline $\mathbf{T}_{7}$ & All - Mg & 21.7 & 21.7 & 18.3 & 135.0 & 25.7 & 63.9 & 3.6 & 79.5 \\
\hline $\mathrm{T}_{8}$ & All - Cu & 21.0 & 21.0 & 18.0 & 135.3 & 25.8 & 64.0 & 3.6 & 80.8 \\
\hline $\mathrm{T}_{9}$ & All - Zn & 20.7 & 20.7 & 17.7 & 133.0 & 25.7 & 58.6 & 11.7 & 73.4 \\
\hline $\mathrm{T}_{10}$ & All - B & 21.3 & 21.3 & 18.0 & 133.7 & 25.7 & 60.6 & 8.7 & 75.2 \\
\hline $\mathbf{T}_{11}$ & All - Mo & 21.0 & 21.0 & 18.3 & 133.0 & 25.7 & 60.7 & 8.5 & 75.5 \\
\hline & SEm \pm & 1.10 & 0.68 & 0.63 & 1.47 & 0.04 & 2.63 & - & 3.20 \\
\hline & at $5 \%$ level & 3.26 & 2.01 & 1.87 & 4.37 & NS & 7.81 & - & 9.51 \\
\hline
\end{tabular}

Table.3 Effect of nutrient omission on total uptake of nutrients by rice (variety: MTU-1001) in Inceptisol of Bastar plateau of Chhattisgarh

\begin{tabular}{|c|c|c|c|c|c|c|c|c|c|c|c|c|}
\hline \multicolumn{2}{|c|}{ Treatments } & \multicolumn{3}{|c|}{ Primary nutrients uptake (g pot ${ }^{-1}$} & \multicolumn{3}{|c|}{ Secondary nutrientsuptake $\left(\mathrm{g} \mathrm{pot}^{-1}\right)$} & \multicolumn{5}{|c|}{ Micronutrients uptake (mg pot ${ }^{-1}$ ) } \\
\hline & & $\mathbf{N}$ & $\boldsymbol{P}$ & $\mathbf{K}$ & $\mathbf{C a}$ & Mg & $\mathbf{S}$ & B & $\mathbf{F e}$ & Mn & $\mathbf{Z n}$ & $\mathbf{C u}$ \\
\hline $\mathbf{T}_{1}$ & All (SSNM) & 1.17 & 0.29 & 1.38 & 0.72 & 0.39 & 0.18 & 1.46 & 21.3 & 30.29 & 4.77 & 0.91 \\
\hline $\mathbf{T}_{2}$ & All - $\mathbf{N}$ & 0.59 & 0.14 & 0.72 & 0.37 & 0.20 & 0.09 & 0.72 & 11.2 & 16.00 & 2.48 & 0.47 \\
\hline $\mathbf{T}_{3}$ & All - P & 0.74 & 0.17 & 0.88 & 0.45 & 0.25 & 0.11 & 0.89 & 13.6 & 19.17 & 3.02 & 0.57 \\
\hline $\mathbf{T}_{4}$ & All - K & 1.15 & 0.28 & 1.34 & 0.70 & 0.38 & 0.17 & 1.38 & 20.9 & 29.71 & 4.65 & 0.88 \\
\hline $\mathbf{T}_{5}$ & All - S & 0.98 & 0.23 & 1.19 & 0.60 & 0.32 & 0.14 & 1.15 & 16.9 & 24.99 & 3.95 & 0.76 \\
\hline $\mathrm{T}_{6}$ & All - Ca & 1.12 & 0.28 & 1.32 & 0.67 & 0.36 & 0.16 & 1.37 & 20.5 & 28.94 & 4.53 & 0.85 \\
\hline $\mathrm{T}_{7}$ & All - Mg & 1.10 & 0.28 & 1.31 & 0.66 & 0.37 & 0.17 & 1.32 & 20.4 & 29.31 & 4.50 & 0.85 \\
\hline $\mathrm{T}_{8}$ & All - Cu & 1.10 & 0.27 & 1.32 & 0.68 & 0.37 & 0.17 & 1.35 & 20.6 & 29.04 & 4.58 & 0.84 \\
\hline$T_{9}$ & All - Zn & 1.05 & 0.26 & 1.20 & 0.64 & 0.35 & 0.16 & 1.27 & 19.2 & 26.46 & 4.26 & 0.82 \\
\hline $\mathbf{T}_{10}$ & All - B & 1.04 & 0.26 & 1.24 & 0.65 & 0.35 & 0.16 & 1.23 & 19.4 & 27.29 & 4.32 & 0.82 \\
\hline $\mathbf{T}_{11}$ & All - Mo & 1.05 & 0.27 & 1.25 & 0.65 & 0.36 & 0.16 & 1.29 & 19.2 & 27.45 & 4.33 & 0.83 \\
\hline & SEm \pm & 0.045 & 0.036 & 0.070 & 0.030 & 0.019 & 0.009 & 0.082 & 0.830 & 1.498 & 0.216 & 0.036 \\
\hline CD & $5 \%$ level & 0.134 & 0.106 & 0.170 & 0.090 & 0.055 & 0.027 & 0.243 & 2.466 & 4.450 & 0.641 & 0.107 \\
\hline
\end{tabular}


Table.4 Grain yields of wheat $\left(\mathrm{qha}^{-1}\right)$ in relation to SSNM and FPD in Inceptisol of Bastar district

\begin{tabular}{|c|l|c|}
\hline S. No. & Treatments & Grain yield $\left(\mathbf{q} \mathbf{h a}^{-1}\right)$ \\
\hline 1 & SSNM dose & 26.4 \\
\hline 2 & Farmers fertilizer dose & 23.3 \\
\hline
\end{tabular}

\section{Plant nutrient uptake}

\section{Primary nutrients}

\section{Nitrogen}

The data in Table 3 indicated that the nitrogen uptake by rice was significantly affected with application of different missing nutrient treatments. Omission of N, P and S in Inceptisol of Bastar district significantly reduced the $\mathrm{N}$ uptake by rice as compared to treatment $T_{1}$ where all the nutrients were supplied.

The highest $\mathrm{N}$ uptake of $1.17 \mathrm{~g} \operatorname{pot}^{-1}$ was recorded in the treatment that received all the nutrients and that of the lowest $\mathrm{N}$ uptake of 0.59 $\mathrm{g} \mathrm{pot}^{-1}$ was recorded in the pots where $\mathrm{N}$ was omitted. Supply of all the nutrients including nitrogen in "All" treatment increased the grain and straw yields as well as the nitrogen concentrations causing more uptake of N (Syed et al., 2006). Minimum nitrogen uptake was observed with nitrogen omission because nitrogen was the most yield limiting nutrient which resulted in lower yields and lower nitrogen uptake. The similar findings were also reported by Mishra et al., (2007).

\section{Phosphorus}

Omission of N, P and S in Inceptisol of Bastar district significantly reduced the total $\mathrm{P}$ uptake by rice as compared to treatment $T_{1}$ where all the nutrients were supplied (Table 3). All the other nutrient omission treatments were found statistically at par with the treatment $\mathrm{T}_{1}$. The highest total uptake of $\mathrm{P}$ by rice was recorded to the tune of $0.29 \mathrm{~g} \mathrm{pot}^{-1}$ in Inceptisol of Bastar district under the treatment $\mathrm{T}_{1}$ where all the nutrients were applied. The lowest total $\mathrm{P}$ uptake $\left(0.14 \mathrm{~g} \mathrm{pot}^{-1}\right)$ by rice was observed in the $\mathrm{N}$ missing treatment followed by $\mathrm{P}$ and $\mathrm{S}$ omission treatments.

Reductions in $\mathrm{P}$ uptakes with omission of $\mathrm{N}, \mathrm{P}$ and $\mathrm{S}$ have also been reported by Mishra et al., (2007) for rice crop and reductions in $\mathrm{P}$ concentration with omission of $\mathrm{P}$ have been reported by Din et al., (2001) for chickpea. Supply of P in "All" treatment increased the soil solution $\mathrm{P}$ causing higher absorption of $\mathrm{P}$ resulting in higher grain and straw yields as well more uptake of $\mathrm{P}$ because $\mathrm{P}$ was the next most yield limiting nutrient after $\mathrm{N}$, which resulted in lower yields and lower $\mathrm{P}$ concentrations.

\section{Potassium}

Total $\mathrm{K}$ uptake by rice was significantly affected with application of different nutrient omission treatments in Inceptisol of Bastar district (Table 3). Omission of N, P and $\mathrm{S}$ significantly reduced the $\mathrm{K}$ uptake by rice as compared to treatment $T_{1}$ where all the nutrients were supplied.

All the other nutrient omission treatments were found statistically at par with the treatment $T_{1}$. The highest $\mathrm{K}$ uptake $\left(1.38 \mathrm{~g}\right.$ pot $\left.^{-1}\right)$ was registered in the treatment $T_{1}$ that received all the nutrients and the lowest $\mathrm{K}$ uptake $(0.72 \mathrm{~g}$ pot $^{-1}$ ) in the $\mathrm{N}$ omission treatment.

\section{Secondary Nutrients uptake}

\section{Calcium Uptake}

The highest Ca uptake $\left(0.72 \mathrm{~g} \mathrm{pot}^{-1)}\right.$ by rice crop was observed in treatment $\mathrm{T}_{1}$ that received all the nutrients. Omission of N, P and S nutrients significantly reduced the $\mathrm{Ca}$ uptake in 
comparison to treatment $\mathrm{T}_{1}$, and the least uptake (0.37and $\mathrm{g} \mathrm{pot}^{-1}$ ) was observed in $\mathrm{N}$ omission followed by $\mathrm{P}$ and $\mathrm{S}$ omission pots.

Omission of $\mathrm{N}, \mathrm{P}$ and $\mathrm{S}$ reduced the total $\mathrm{Ca}$ uptakes by rice in comparison to the treatments receiving all the nutrients. Omission of $\mathrm{N}, \mathrm{P}$ and $S$ reduced the uptakes more than that of omission of other nutrients indicating that these nutrients were the most limiting nutrients. Lower Ca uptakes were observed with N, P and $\mathrm{S}$ omission obviously due to lower grain and straw yields and lower $\mathrm{Ca}$ concentrations. Uptakes of $\mathrm{Ca}$ in $\mathrm{N}, \mathrm{P}$ and $\mathrm{S}$ omitted pots were in the order of $\mathrm{N}<\mathrm{P}<\mathrm{S}$ in accordance with the grain and straw yields and $\mathrm{Ca}$ concentrations in the respective pots. Least reductions in $\mathrm{Ca}$ uptakes were observed with omission of $\mathrm{K}, \mathrm{Ca}$, $\mathrm{Mg}, \mathrm{Cu}, \mathrm{Zn}, \mathrm{B}$ and Mo suggesting their sufficient level in the experimental soil (Table 3).

\section{Magnesium uptake}

The highest total uptake of $\mathrm{Mg}\left(0.39 \mathrm{~g} \mathrm{pot}^{-1}\right)$, was observed with the treatment receiving all the nutrients, because supply of all the nutrients including $\mathrm{Mg}$ in All nutrients treatment increased the grain and straw yields as well as the $\mathrm{Mg}$ concentrations causing more uptake of $\mathrm{Mg}$, whereas, the least $\mathrm{Mg}$ uptake $\left(0.20 \mathrm{~g} \mathrm{pot}^{-1}\right)$ were observed with $\mathrm{N}$ omission treatment. Reduced Mg uptake was observed with $\mathrm{N}, \mathrm{P}$ and $\mathrm{S}$ omission treatments, since these were the most yield limiting elements. Mg uptakes were found almost similar in all the other treatments in comparison to $T_{1}$ which might be due to higher initial $\mathrm{Mg}$ content in the soil under study. Uptakes of $\mathrm{Mg}$ in $\mathrm{N}, \mathrm{P}$ and $\mathrm{S}$ omitted pots were in the order of $\mathrm{N}<\mathrm{P}<\mathrm{S}$ in accordance with the grain and straw yields and $\mathrm{Mg}$ concentrations in the respective pots (Table 3 ).

\section{Sulphur uptake}

The highest $\mathrm{S}$ uptake in Inceptisol $\left(0.18 \mathrm{~g} \mathrm{pot}^{-1}\right)$ were recorded in treatment $T_{1}$ which received all nutrients and the least total uptake of $\mathrm{S}(0.09$ g pot ${ }^{-1}$ ) was observed in the treatment $T_{2}$ that omit $\mathrm{N}$ nutrient. Omission of $\mathrm{N}, \mathrm{P}$ and $\mathrm{S}$ caused significantly lower uptake of $\mathrm{S}$, in comparison to treatment that received all the nutrients (Table 3).

\section{Verification at farmer's fields}

Based on the performance of rice crop during Kharif season (2017), the N, P, and S nutrients were identified as yield limiting nutrients in Inceptisol of Bastar district. These nutrients were applied at the rate of $150 \mathrm{~kg} \mathrm{~N}, 100 \mathrm{~kg}$ $\mathrm{P} 2 \mathrm{O} 5,100 \mathrm{~kg} \mathrm{~K} 2 \mathrm{O}$, and $45 \mathrm{~kg} \mathrm{~S}^{-1}$.

This dose, known as SSNM dose was tested at farmers field, from where the bulk soils were collected for pot experiments, with wheat crop (variety: GW- 273) during rabi 2017-18. The wheat crop was shown on $15^{\text {th }}$ December 2017 and harvested on $4^{\text {th }}$ April 2018. The farmer's applied fertilizer doses at the rate of $80 \mathrm{~kg} \mathrm{~N}: 50$ kg P2O5: 0 kg K2O ha ${ }^{-1}$.

\section{Yield of wheat crop}

The final grain yields of wheat in farmer's fields testing sites was recorded and presented in Table 4. The wheat grain yields at farmer's fields was higher in SSNM dose, applied based on the yield limiting nutrients, as compared to that of farmer's practice dose. About $13.3 \%$ increase in the wheat grain yield was recorded over farmer's practice dose.

This testing confirmed that application of identified yield limiting nutrients as $\mathrm{N}, \mathrm{P}$ and $\mathrm{S}$ in Inceptisols, were the yield limiting nutrients.

Similarly, Khurana et al., (2008) also reported $12-17 \%$ increase in grain yield due to site specific nutrient management. Khurana et al., (2006) also reported $17.7 \%$ increase in grain yield, 13 to $15 \%$ increasein plant $\mathrm{N}, \mathrm{P}$, and $\mathrm{K}$ accumulations, $14 \%$ increase in the gross return with SSNM than with FFP and increased N recovery efficiency from $0.20 \mathrm{~kg} \mathrm{~kg}^{-1}$ in FFP plots to $0.30 \mathrm{~kg} \mathrm{~kg}^{-1}$ in SSNM plots due to improved timing and/or splitting of fertilizer $\mathrm{N}$. 


\section{References}

Ahmed, S., Elahi, N., Khan, R., Faridullah, J. and Din, N. 2010. Wheat response to phosphorus under climatic conditions of Juglote, Pakistan Sarhad. J. Agri., 26: 229-33.

Din, J., Rashid, A. and Zahid, M.A. 2001. Optimizing productivity and profitability in rain fed legume crops through balanced nutrient management. Pakistan J. Soil Sci., 20 (4): 70-74.

Havlin, J.L., Tisdale, S.L., Beaton, J.D. and Nelson, W.L. 2007. Soil fertility and fertilizers - an introduction to nutrient management. Dorling Kindersley Pvt. Ltd., New Delhi, India, 175.

Khurana, H. S., Phillips, S. B., Singh, B., Dobermann, A., Sidhu, A. S., Singh, Y. and Peng, S. 2006. Performance of sitespecific nutrient management for irrigated, transplanted rice in Northwest India. American Society of Agronomy, 10: 2134.

Khurana, H. S., Singh B., Dobermann, A, Phillips, S. B., Sidhu, A. S. and Singh, Y. 2008. Site specific nutrient management performance in a rice-wheat cropping system. Better Crops - India. pp. 26-28.

Mc-Beath, T., MMc-Laughlin, M.J., Armstrong, B.R.D., Bell, M., Bolland, M.D.A. Conyers, M.K., Holloway, R.E. and Mason, S.D. 2007. Predicting the response of wheat (Triticum aestivum L.) to liquid and granular phosphorus fertilisers in Australian soils. Australian J. Soil Res., 45: 448- 458.

Mishra, V. N., Patil, S. K., Das, R. O. Shrivastava, L. K., Samadhiya, V. K. and Sengar, S. S. 2007. Site-specific nutrient management for maximum yield of rice in Vertisol and Inceptisols of Chhattisgarh. A paper presented in South Asian Conference on "Water in Agriculture: management options for increasing crop productivity per drop of water", during November, 15-17, 2007 held at IGKV, Raipur (C.G.), India. pp. 136.

Sahu, N., Mishra, V.N., Srivastava, L.K. and Jatav, G. 2017. Crop Response based Assessment of Limiting Nutrients using Site Specific Nutrient Management for Yield Maximization in Vertisols of Bemetara Districts of Chhattisgarh, India. Int. J. Curr. Microbiol. App. Sci., 6(6): 1784-1791.

Sharma, P.K., Yadav, G.L. and Kumar, S. 2000. Response of wheat to nitrogen and zinc fertilization. Indian J. Agro., 45(1): 124127.

Syed, T.H., Ganai, M.R., Tahir Ali and Mir, A.H. 2006. Effect of nitrogen and sulphur fertilization on yield of and nutrient uptake by sunflower. J. Indian Soc. Soil Sci., 54(3): 375-376.

\section{How to cite this article:}

Bhupendra Kumar, G.K. Sharma, V.N. Mishra, T. Chandrakar, A. Pradhan, D.P. Singh and Thakur, A.K. 2018. Assessment of Yield Limiting Nutrients through Response of Rice (Oryza sativa L.) to Nutrient Omission in Inceptisols of Bastar District of Chhattisgarh State in India. Int.J.Curr.Microbiol.App.Sci. 7(08): 3972-3980. doi: https://doi.org/10.20546/ijcmas.2018.708.410 